\title{
COVID-19 in the maritime setting: the challenges, regulations and the international response
}

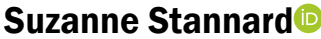

Norwegian Centre of Maritime and Diving Medicine, Department of Occupational Medicine, Haukeland University Hospital, Bergen, Norway

\section{INTRODUCTION}

The maritime industry is responsible for the transport of about $90 \%$ of the world's trade [1]. Throughout the current pandemic, the industry has striven to maintain supply chains and the delivery of essential cargoes, including food and medical supplies, whilst ensuring the continued health and welfare of the 1.6 million seafarers serving on board ships. It has faced many challenges and these have been met by an unprecedented level of international, cross industry collaboration. All of the United Nations (UN) Agencies, the International Chamber of Shipping (ICS), the International Transport Workers Federation (ITF), the International Maritime Health Association (IMHA), the International Seafarer's Welfare Association (ISWAN) and many more organisations and governments, at an international and national level, have worked tirelessly in an attempt to manage these issues.

\section{CHALLENGES FACING THE MARITIME INDUSTRY}

The key areas that have challenged the industry include but are not limited to:

- the management of an active case on board;

- the need to establish physical distancing and other measures to reduce the spread of the disease on a ship;

- access to pre-employment medical examination;

- interaction with shore staff in ports;

- crew changes;

- access to medical, dental and welfare services in port;

- reduced possibilities for shore leave;

- contract extension;

- increase in mental health issues in seafarers on board. The International Maritime Organisation (IMO) and the International Labour Organisation (ILO) recognised many of these issues back in February and the IMO issued Circular Letter 4204/1 [2] on February $19^{\text {th }}$. This identified the international instruments in place that may be relevant to the management of a pandemic and clearly stated the responsibility of all nations to adhere to these and to the Maritime Labour Convention (MLC) 2006 [3].

\section{WHAT, WHEN, HOW MANY?}

First reported in Wuhan, China in the last months of 2019, the current outbreak of COVID-19, caused by the SARS-CoV-2, virus was declared a pandemic by the Director-General of the World Health Organization (WHO) on March $11^{\text {th }} 2020$. At the time of writing, over 9 million cases have been reported, with over 470,000 deaths [4] and the numbers continue to increase. The illness spreads by direct or indirect contact with droplets from an infected person and in order to slow the spread of the disease, and reduce the pressure on health services, many countries introduced 'lockdown' measures. These measures remain in place in many countries, to a greater or lesser degree, and have a major impact on the maritime industry.

No figures are currently available for the actual number of cases identified amongst crew serving on board a ship. Outbreaks on cruise ships such as the Diamond Princess and the Holland America ship, Zaandam, were widely reported in the press and in scientific journals [5]. However, reports in the press or journals of cases or outbreaks on non-passenger ships including fishing vessels, are few, suggesting that the number of cases on board these ships are limited. However, we know that there are cases on board ships as far afield as Brazil, Mozambique, Antwerp and China and some of these have unfortunately led to the death of seafarers [6]. 


\section{MANAGEMENT OF COVID-19 ON BOARD}

In accordance with the International Ship Management (ISM) Code [7] or other applicable regulatory instruments, shipping companies are required to assess all identified risks to their ships and personnel and establish appropriate safeguards, normally documented in their Safety Management Systems (SMS). Therefore, shipping companies should develop plans and procedures to address the risks to the health of seafarers and the safety of their ship operations posed by the current pandemic, including a case or a number of cases on board.

If a crewmember develops signs and symptoms suggestive of possible COVID-19, he/she should report these to the medical officer immediately. The crewmember should be isolated in the sick bay or his/her own cabin, preferably with access to a bathroom that is not used by others, and assessed further. Isolation of a crewmember may be very challenging depending on the size and design of the ship. Meals should be delivered to the cabin and a full cleaning protocol instigated.

Assistance with making a diagnosis is available at COVID-19 at sea [8], designed by the Norwegian Centre of Maritime and Diving Medicine to assist in diagnosis and supportive care. The ICS publication, "COVID-19 - Guidance for Ship Operators for the Protection of the Health of Seafarers" [9] gives further advice for the management of the case and possible contacts.

The early recognition and close monitoring of a case is key to its successful management and that is one advantage of a shipboard environment. The sick seafarer should be monitored in person or by telephone, two to three times a day and a record kept of his/her symptoms and vital signs. Any deterioration should be a trigger for referral to a Telemedical Assistance Service (TMAS) or other shore side medical support. Early access to oxygen and to more advanced medical care, if required, is essential and this has proven to be a potential issue for seafarers.

The ship must report all suspect cases to the relevant health authorities at the next port of call as per the International Health Regulations (2005) [10]. For ships on an international voyage and calling at a foreign port, the Maritime Declaration of Health must be completed.

\section{MANAGEMENT OF CLOSE CONTACTS ON BOARD}

In a shipboard environment the sick crewmember is likely to have been in contact with many/most of the other seafarers, depending upon the size of the ship, number of crew on board and of course the position of that seafarer. The WHO publication "Operational considerations for managing COVID-19 cases or outbreaks on board ships: interim guidance" [11] published in March 2020, defines a close contact as anyone who has "had physical contact (face to face contact within 1 metre for more than $15 \mathrm{~min}$ ) or were in a closed environment with a suspected or confirmed COVID-19 case'. In addition, close contacts are those who have shared a cabin and those that have provided medical care to a suspect case. The ICS guidance advises that close contacts, and therefore crewmembers at high risk of transmission of the virus specifically include those that have:

- had close contact within 1 metre or were in a closed environment with a suspect/confirmed COVID-19 case (for example tank work, shared watch in an engine control room, eaten a meal with);

- participated in the same immediate travelling group without quarantine before boarding the ship;

- been a cabin steward who cleaned the cabin of a suspect/confirmed case of COVID-19.

If the number of high risk close contacts is relatively small they should be asked to quarantine, if to do so would not endanger the safety of the ship, those on board or the ship's operation.

On a small ship, if one seafarer develops possible COVID-19, all crewmembers will be close contacts and should therefore quarantine for up to 14 days depending on local advice. Obviously, this is impractical on such a vessel as operations would be severely impaired and the ship unable to function. In these circumstances, all crewmembers should self-monitor for symptoms and report anything suggestive of COVID-19 immediately. Daily temperature screening may also be appropriate, as may the wearing of a face covering.

\section{THE USE OF PERSONAL PROTECTIVE EQUIPMENT ON BOARD}

The MLC 2006 states that each member shall ensure that all seafarers on ships that fly its flag are covered by adequate measures for the protection of their health. The use and availability of personal protective equipment (PPE) should be included in the risk assessment completed as above. Guidelines for the use of PPE on board a ship have been published by the European Healthy Gateways in its document 'Who, Where, How' [12], released in May 2020. In order to comply with these recommendations, ship owners must ensure that there are adequate amounts of the required PPE on board. Recommendations differ for well crewmembers and in the scenario of a suspect case on board. All crewmembers who encounter a suspect case should wear a medical mask and gloves whilst those providing medical care are advised to use a medical mask or FFP2 respirator (prioritised for aerosol generating procedures), gloves, a gown and visor/goggles. Crew will need information on how to safely use this equipment as this is not currently covered in the STCW Medical Care course, although maybe this is a consideration for the future. Such advice on the safe use of PPE is available from the WHO and the ICS in their publications. 


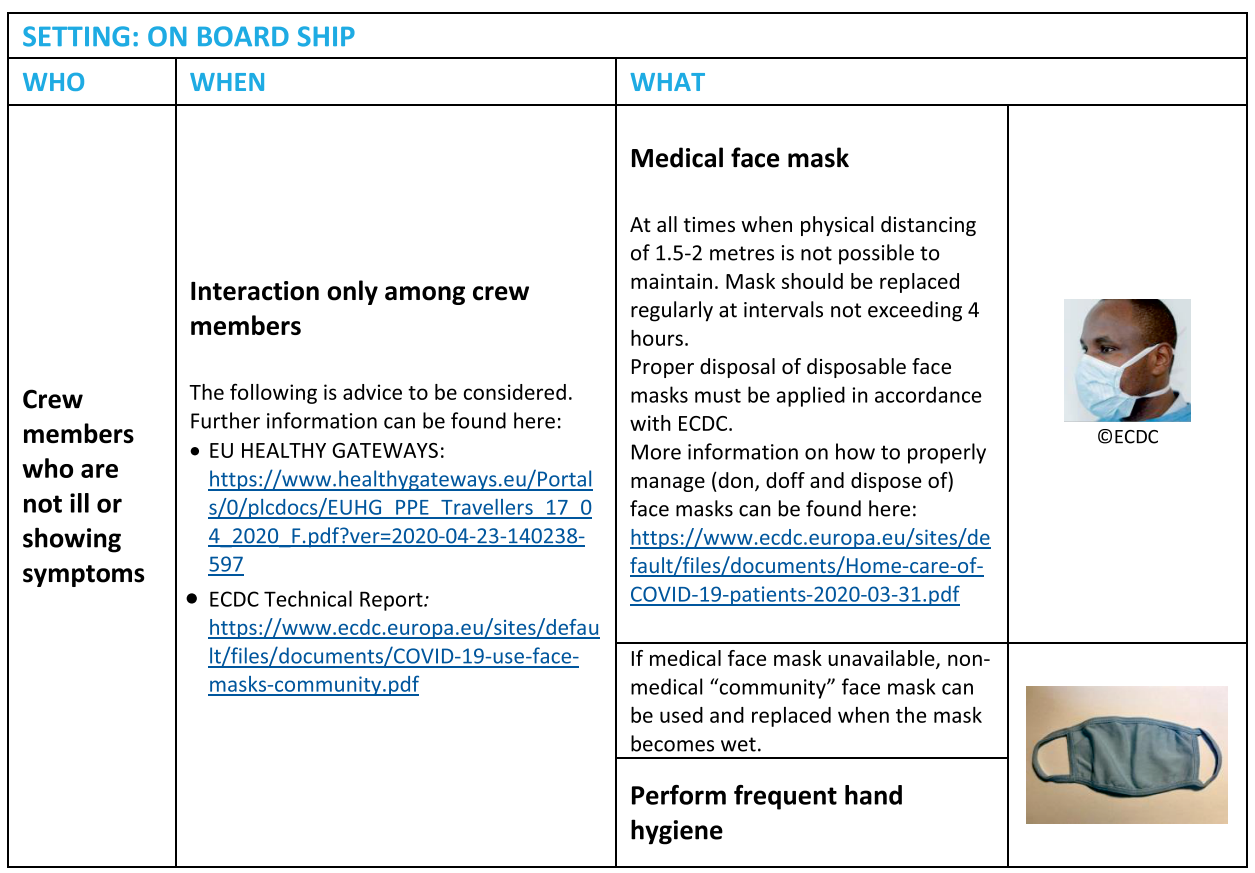

Recommended personal protective equipment for crew members not ill or showing symptoms. From: European Healthy Gateways: https://www.healthygateways.eu/Portals/0/plcdocs/EUHG_PPE_ Overview_24_04_2020_F.pdf?ver=2020-05-20-201841-010 (page 26) (Accessed June $25^{\text {th }}$ 2020)

\section{INTERACTION WITH SHORE BASED STAFF}

Early advice from the IMO gave the recommendation to limit the number of interactions with shipboard personnel to 'only those critical and essential for the continued operation and supply of the ship' and also to ensure that those working in ports 'are provided with appropriate personal protective equipment... prior to contact with seafarers'. Whilst this may give the impression of being in place to protect port workers from seafarers, the risk may well be greater the other way around. Initial studies, yet unpublished, suggest that the incidence of COVID-19 in crew joining a ship and in port staff is equivalent to that in the general population. On the other hand, a ship's crew that has been at sea with no contact from the 'outside world' for 14 days may be considered 'free' of COVID-19. Taking into the account the potential risk for transmission in either direction the IMO published Circular Letter 4204/Add.16 [13] in May 2020 outlining a risk management plan for ship: shore interaction. Additional information is also found in the ICS Guidance document. It must also be noted that the requirements for workers and the general public to wear PPE, and in particular face coverings, vary between countries and good communication is essential to ensure that shipboard and local requirements are met.

\section{CREW CHANGE}

The issues surrounding crew change are many and include but are not limited to:
- The availability or not of travel from the seafarer's home to the port. This may involve travel by road, sea and air and may involve crossing country borders. Whilst air travel is slowly increasing again after many months of very limited availability, not all routes are open and schedules are liable to change at short notice leaving crew stranded.

- Entry restrictions and quarantine requirements in the country where the seafarer should join the ship or the seafarer's home country. Some of these can be lifted or eased if countries identify seafarers as key workers. However, a few countries remain closed to all, including their own citizens trying to return home, and there may be significant restrictions to travel within a country. Many seafarers remain on cruise ships in Manila Bay awaiting permission to go ashore and get home having been brought to the Philippines on board ships [14].

- Quarantine and testing requirements developed by the shipping company designed to protect crew on board by reducing the risk of new crew introducing the virus when they board.

The difficulties of changing crew became apparent very early in the pandemic and many organisations have highlighted this as an increasing cause for concern. The MLC 2006 clearly states that seafarers have the right to be repatriated at no cost to themselves, and states a default period of a maximum service of 11 months. Under the claim of 'force majeure', companies have extended crew contracts 
beyond this and seafarers are spending an ever increasing period at sea. Maritime Bergen hosted a webinar concerning this subject in March and other organisations outside of the UN agencies and social partners have highlighted the issue in various publications [15]. Simultaneously the UN agencies, the ICS, ITF and others approached various governments in order to ensure that countries recognise seafarers as key workers and are therefore exempt from quarantine and travel restrictions that they impose on the public. Examples of action include:

- an open letter [16] to UN agencies from the ICS and ITF on March $19^{\text {th }}$ 2020;

- a statement of the officers of the Special Tripartite Committee of the MLC 2006 [17] on March 31 $1^{\text {st }} 2020$;

- an information note on maritime labour issues and COVID-19 [18] produced by the ILO on April $7^{\text {th }} 2020$;

- a 12 step plan [19] produced by the IMO and published on May $6^{\text {th }}$ to assist governments to put in place coordinated procedures to allow the safe movement of seafarers to and from ports;

- a joint statement [20] from the IMO, ILO and International Civil Aviation Organisation (ICEO) on May $28^{\text {th }}$ calling on governments to designate seafarers as key workers and facilitate crew changes;

- a call from the UN [21] on June $12^{\text {th }}$ to ensure that seafarers are recognised as key workers.

At the time of writing, this has not been resolved satisfactorily and there are estimated to be around 200,000 seafarers who remain on board after the end of their contract because it remains impossible to make crew changes at many ports around the world.

\section{TESTING}

Testing for COVID-19 and in particular, the role of tests in crew change is a matter of much discussion. Testing policies and therefore the availability of tests, varies hugely around the world, as do the requirements of different countries and different shipping companies. Whilst 14 days of quarantine at the point of embarkation is the ideal way to try to ensure that new joiners do not carry on board COVID-19, this is often very difficult to arrange. Countries and ship owners have developed different strategies to try to reduce the risk of introducing the virus on board, including quarantine in the home country pre-travel to the ship and, in some cases, the use of testing.

The polymerase chain reaction test is the most accurate to detect the presence of the virus but it is not widely available out of a health care setting and still has up to a $30 \%$ false negative rate, often related to how the swab was taken. These tests can certainly not be used on board. Rapid diagnostic tests to detect either the virus antigen or antibodies produced because of prior infection are not yet accurate enough for use outside of a research or health care setting [22].

Any test only provides a snapshot of the moment it was taken. It cannot predict whether a seafarer will develop COVID-19 in the coming days. Whilst a positive test at any point will ensure a seafarer with the virus does not travel or board the ship, a negative test should be interpreted with care and in the context of any clinical findings. At present, testing can only form a small part of the overall risk assessment and cannot be used to exclude all risk. As an example, as part of the agreed local policy, one clinic has tested 650 crew prior to joining a ship. Seven $(1 \%)$ have tested positive although only half of those displayed symptoms at the time of testing. However, on one ship following the same policy there is currently one seafarer hospitalised and four seafarers with confirmed COVID-19. No system is ideal.

\section{ACCESS TO MEDICAL CARE OVERSEAS}

The International Health Regulations (2005) clearly state that ships should not be prevented from entering port and embarking or disembarking persons on board for public health reasons. Equally, MLC 2006 makes it clear that all states shall ensure that seafarers in its territory in need of immediate medical care are given access to medical facilities with the "right to visit a qualified medical doctor or dentist without delays in ports of call, where practicable'.

Health care provision and policies regarding occupational health protection vary widely across the world. In the current pandemic situation, health care systems are often stretched and in many countries, governments have placed restrictions on the opening, availability and ways of working for health care providers. This means that some services or treatments are not available to the local population and therefore not available to seafarers arriving in these ports. However if the service is available ashore it is clearly stated in the MLC that it should also be available to seafarers. In many instances, in many ports, this is the case. However, there are some examples, in some places, of ships refused entry to port and seafarers refused the right to disembark to seek urgent medical care. Examples range from the assessment of possible COVID-19 cases to the assessment and treatment of appendicitis and assessment of chest pain likely due to ischaemic heart disease. There was also the widely publicised case of a seafarer who suffered a cerebrovascular event and the nearest port refused permission for the ship to enter and medivac the seafarer for further assessment. Only after intervention by the UN agencies did this seafarer receive appropriate care [23]. There can be no defence of such actions by individu- 
al countries. On the other hand, Radio Medico Norway have had cases where the seafarer, captain and ship owner/manager have made it clear that they do not want to enter port and disembark a sick seafarer but would rather treat the seafarer on board. TMAS doctors provided medical advice in these situations, far and above 'normal'. Equally we know that there are port health facilities open and willing to see and treat seafarers but seafarers are not keen to leave the 'safety' of the ship and visit facilities ashore.

As more and more health care providers use telephone or video consultations for their usual patients, the availability of a remote consultation for a seafarer should be better than ever before. This requires good communication between the ship, the port agent and the medical facility, but is possible. Particularly whilst a ship is in port, the crew have the right to obtain medical care as required and they should do so. If not, there is a risk that a ship leaves the safe haven of a port with a sick crewmember on board.

Remote consultations are also very useful to obtain repeat prescriptions for long-term medication. There are an increasing number of requests for prescriptions as seafarers extend their contracts on board because of the issues in changing crew. The problem here may not be so much in speaking to or seeing the relevant professionals shore side, but more in identifying the medication required and ensuring it is available in a different country to the seafarer's home. Again, with good and timely communication this can usually be resolved.

\section{MENTAL HEALTH ISSUES}

The mental health of seafarers has been of concern for some time and the current pandemic has highlighted it further.

Natalie Shaw, Director of Employment Affairs at the ICS, suggests some of the reasons for the current increase in mental health issues include:

- extended periods at sea beyond the normal contract length;

- conflicting information from different sources;

- pressures to get home from family members;

- caring responsibilities back home;

- concern around family member's health in vulnerable cities and locations;

- concern about longer term financial stability;

- difficulty in getting shore leave and access to ship visitors and port welfare centres;

_ increased isolation resulting from the requirement to remain on board;

_ inaccurate media and fake messaging;

- limited medical facilities and equipment;
- inaccurate media and fake media messaging;

- potential to be infected with COVID-19 when travelling from home to ship, ship to home or visiting port facilities;

- limited medical facilities and equipment on board cargo ships;

- less access to general medical care ashore because of local health care restrictions;

- limited training for those administering medical care on board cargo vessels and limited ability to handle an outbreak of COVID-19 on board;

- difficulties in procuring supplies to restock in certain ports.

Organisations such as ISWAN have provided assistance to seafarers though their helpline and with online advice as seafarer's centres and welfare facilities remain closed in many ports. Other organisations have done their best to highlight the issue in an attempt to raise the profile of these seafarers 'trapped on board' by COVID-19 [24]. Despite best efforts, unfortunately there have been a number of reported suicides on board ships [25].

\section{SUMMARY}

Since the beginning of the COVID-19 pandemic the maritime industry has faced many and varied challenges which are affecting the health and welfare of seafarers and may threaten the global supply chain of essential goods. The industry, UN agencies and other, influential organisations have come together in previously unseen levels of cooperation and understanding. I personally have taken part in three webinars aimed at highlighting the issues described here and whilst admittedly progress is slow, much has been done. Application of the various regulatory instruments, cooperation with governments and good communication amongst all parties will ensure that we meet the seafarer's medical and welfare needs whilst the industry continues to fulfil its essential role.

To quote the IMO Secretary General, Kitack Lim, in his document promoting the Day of the Seafarer 2020 on June $25^{\text {th: }}$ 'Seafarers continue to deliver for all of us. Now, let's ensure that we deliver for them!'

\section{REFERENCES}

1. https://www.ics-shipping.org/shipping-facts/shipping-and-world-trade (Accessed June 22nd 2020).

2. http://www.imo.org/en/MediaCentre/HotTopics/Documents/CL. 4204-Add.1\%20English.pdf (Accessed June 25th 2020).

3. https://www.ilo.org/global/standards/maritime-labour-convention/text/WCMS_554767/lang-en/index.htm (Accessed June 25th 2020).

4. https://www.worldometers.info/coronavirus/ (Accessed June 22nd 2020).

5. Dahl E. Coronavirus (Covid-19) outbreak on the cruise ship Diamond Princess. Int Marit Health. 2020; 71(1): 5-8, doi: 10.5603/ MH.2020.0003, indexed in Pubmed: 32212140. 
6. https://www.thehindu.com/news/national/indian-seafarer-dies-of-covid-19-in-florida/article31302638.ece (Accessed June 18th 2020).

7. http://www.imo.org/en/OurWork/HumanElement/SafetyManagement/Pages/ISMCode.aspx (Accessed June 25th 2020).

8. https://helse-bergen.no/en/avdelinger/yrkesmedisinsk-avdeling/ norsk-senter-for-maritim-medisin-og-dykkemedisin/covid-19-at-sea (Accessed June 25th 2020).

9. https://www.ics-shipping.org/docs/default-source/resources/ covid-19-guidance-for-ship-operators-for-the-protection-of-the-health-of-seafarers-v2.pdf?sfvrsn=4 (Accessed June 25th 2020).

10. https://apps.who.int/iris/bitstream/handle/10665/246107/ 9789241580496-eng.pdf;jsessionid=AOE3F22529F1DCD356D207BE1424E7C6?sequence=1 (Accessed June 25th 2020).

11. https://www.who.int/publications/i/item/operational-considerations-for-managing-covid-19-cases-or-outbreaks-on-board-ships-interim-guidance (Accessed June 25th 2020).

12. https://www.healthygateways.eu/Portals/0/plcdocs/EUHG_PPE_ Overview_24_04_2020_F.pdf?ver=2020-05-20-201841-010 (Accessed June 25th).

13. http://www.imo.org/en/MediaCentre/HotTopics/Documents/ COVID\%20CL\%204204\%20adds/Circular\%20Letter\%20No. 4204-Add.16\%20-\%20Coronavirus\%20(Covid\%2019)\%20-\%20 Covid-19\%20Related\%20Guidelines\%20For\%20Ensuring\%20A\%20 Safe\%20Shipboard.pdf (Accessed June 25th).

14. https://www.theguardian.com/environment/2020/may/14/ deaths-and-hunger-strikes-point-to-mental-health-crisis-on-stranded-cruise-ships (Accessed June 18th 2020).

15. https://www.chirpmaritime.org/wp-content/uploads/2020/04/ Trapped-on-board-April-2020-.pdf (Accessed June 16th 2020).
16. https://www.ics-shipping.org/news/press-releases/view-article/2020/03/19/joint-open-letter-to-united-nations-agencies-from-the-global-maritime-transport-industry (Accessed June 25th).

17. https://www.ilo.org/global/standards/maritime-labour-convention/ special-tripartite-committee/WCMS_740130/lang--en/index.htm (Accessed June 25th).

18. https://www.ilo.org/global/standards/maritime-labour-convention/ WCMS_741024/lang-en/index.htm (Accessed June 25th).

19. http://www.imo.org/en/MediaCentre/HotTopics/Documents/ COVID\%20CL\%204204\%20adds/Circular\%20Letter\%20No. 4204-Add.14\%20-\%20Coronavirus\%20(Covid-19)\%20-\%20 Recommended\%20Framework\%200f\%20Protocols.pdf (Accessed June 25th).

20. https://www.ilo.org/sector/Resources/WCMS_745870/lang-en/ index.htm (Accessed June 25th 2020).

21. https://www.un.org/sg/en/content/sg/statement/2020-06-12/ statement-attributable-the-spokesman-for-the-secretary-general-the-repatriation-of-seafarers (Accessed June 25th 2020).

22. https://www.who.int/news-room/commentaries/detail/advice-on-the-use-of-point-of-care-immunodiagnostic-tests-for-covid-19 (Accessed June 22nd 2020).

23. http://www.imo.org/en/MediaCentre/HotTopics/Pages/Support-for-seafarers-during-COVID-19.aspx (Accessed June 18th 2020).

24. https://www.chirpmaritime.org/wp-content/uploads/2020/04/ Covid-19-psycology-and-welfare-paper-April-2020-Final.pdf (Accessed June 18th 2020).

25. https://www.offshore-energy.biz/covid-19-agony-2-more-cruise-ship-crew-members-die-while-awaiting-repatriation/Accessed (Accessed June 18th 2020). 